\title{
The Contribution of Ethical Leadership in Promoting the Educational and Learning Process in Greece
}

\author{
Panagiotis Geropoulos (Corresponding author) \\ Philologist, $\mathrm{PhD}$ Candidate \\ Aristotle University of Thessaloniki, Greece \\ E-mail: panos_geropoulos@yahoo.com
}

Kostis Tsioumis

Professor, School of Philosophy \& Education

Aristotle University of Thessaloniki, Greece

E-mail: ktsioumi@edlit.auth.gr

Received: January 30, 2022

Accepted: February 25, 2022 Published: February 27, 2022

doi:10.5296/jet.v9i2.19523

URL: https://doi.org/10.5296/jet.v9i2.19523

\begin{abstract}
The present work aims to approach the characteristics of ethical leadership and to detect the practices applied by the principals of secondary schools to support socially vulnerable groups. In this context, school leaders express views on the structure and "nature" of leadership, and in particular on ethical leadership. At the same time, emphasis is placed on capturing the implementation of actions for the educational support of the specific groups of the population as well as on the existing structure of the Greek educational system that operates restrictively for the undertaking of initiatives by them. It investigates whether the positive influences of ethical administration are not limited to the level of school units. In addition, the work seeks to identify the current problems that principals face in the performance of their duties. The analysis of the data from the 43 semi-structured interviews reveals important facts about the importance of ethical educational leadership and the benefits it can offer to the entire student population and to the operation of the school. In particular, the application of ethical leadership creates the right conditions to improve the learning performance of students, contributes positively to the socialization of vulnerable groups and finally creates a positive educational climate.
\end{abstract}


Keywords: leadership, ethical leadership, management, social justice, educational system, secondary education, social vulnerable groups

\section{Introduction}

The issue of leadership is quite complex and has occupied the scientific community for many years. Various researches have been carried out on this subject. It is important to note that due to the increased complexity of educational environments, the ethical use of power can play an essential role (Walker et al., 2007).

An ideal leader is the person with leadership and managerial skills at the same time (Bourandas, 2005, p.196). Brown and Trevino (2006) argue that the leader of an organization determines its evolution based on the strategies and methods they apply. According to other theorists, leadership style is a key factor in staff performance and effectiveness (Ahmad et al., 2013). There is evidence that good leadership by providing equal opportunities for all in the context of social justice contributes to students' success (Berkovich, 2014). For this reason, it is useful for the school principal to be an ethical and democratic leader, two concepts that are interrelated. The phrase "leadership style" therefore represents the way of behavior applied by the head of the organization in order to motivate employees and create favorable conditions for its operation. In other words, it expresses personality traits which in turn affect the performance of others (Dougali, 2017).

Ethical leadership training seems to have positive consequences and ensure the viability of the organization in the future. In order to better achieve the goals of the school unit, not only the management but also the leadership is necessary. In particular, ethical educational leadership is considered useful for dealing with the modern school environment which is based on values (Cranston et al., 2006).

The term educational leadership and administration refers to the scientific branch that concerns the basic functions of administration focused on educational organizations and learning organizations (Athanasoula-Reppa, 2008, p.14 ). Training leadership relies on the managers who direct their actions towards achieving the goals and motivate the rest of the staff for better performance (Gunter \& Forrester, 2009).

The purpose of this study is to investigate the views of secondary school principals on the concept of ethical leadership. Thus, an effort is made to identify the benefits that result from the application of ethical leadership practices to the entire student population. In this context, the work examines how ethical leadership can "facilitate" the school and social integration of vulnerable groups.

\section{Literature Review}

\subsection{Conceptual Approach to Ethical Leadership}

Ethical leadership is a modern method of managing organizations. In the last 30 years, the amount of research on this model of leadership behavior has increased due to the unethical behaviors of many organizations and companies (Lawton \& Páez, 2015). It began to appear 
in education in the 1990 decade to create greater social justice which is a concept of particularly important value (Langlois, 2014).

As Athanasoula-Reppa (2008) argues, it is the highest stage of transformational leadership. Initially, Starratt (1991) had expressed the view that ethical leadership should not be approached simply as a management style but much more emphasis should be placed on the application of ethical practices (Arar et al., 2016). The extension of the application of ethical leadership is the development of an ethical character and the increased awareness of ethical issues that benefit an individual or a group (Langlois, 2014). Ethical leadership according to research seems to positively affect the well-being of employees and create positive motivation for their work (Kalshoven \& Boon, 2012).

From time to time, various researches have been conducted on ethical leadership and its characteristics. However, there is no universal unanimity regarding the profile of the ethical leader and the number of characteristics they gather (Mitropoulou et al., 2014). A leader is defined as ethical when they are fair, honest, make fair decisions, promote values such as inclusion, cooperation and Social Justice (Ehrich et al., 2015). A related study on ethical leadership, defines it as "displaying appropriate behavior" through personal actions and interpersonal relationships as well as promoting this behavior to followers through two-way communication for reinforcement and right decision making (Arar et al., 2016). Also important is the distinction made between ethical style and others like it. For example, there are significant differences in relationships and traits between ethical, charismatic, authentic, or spiritual leadership (Tumasjan et al., 2011).

\subsection{Characteristics of Ethical Leadership}

In short, the characteristics of ethical leader are concentrated in the display of dignity, honesty, trust and appreciation towards the "followers". As Lawton and Paez (2015) report, ethical leadership is associated with ethical issues as well as with the vision that contributes to the effectiveness of an organization. The leader in this case is the creator of the ethical deontology, the culture as well as the reputation of the organization. Usually, principals do not frame what they do in terms of ethics but think more about the results of their actions. In addition, credibility, honesty, transparency in decision-making and virtue play a key role in ethical leadership (Seidman, 2004). An ethical leader can act, taking into account the above elements. An important element is also the transmission of vision and moral values by the leader to their subordinates, thus ensuring long-term survival and success. The ethical leader is ready to face new challenges and cope better with school problems. On the contrary, research points to unethical behavior leading to reduced performance and consequently to failure (Almandeel \& Dawood, 2019). School is a social system in which students spend a lot of time. It is in this context that they develop their personality, often imitating the principal who can be a role model for them (Almandeel \& Dawood, 2019). In terms of the characteristics of ethical leadership, trust, rewarding ethical behavior, cooperation and ethical responsibility are important elements while altruism and green policy applications seem to be less important (Mitropoulou et al., 2014). 


\subsection{The Concept of Social Justice}

The concept of Social Justice differs according to the definitions given to it and is a term that has many interpretations. In short, efforts to "delimit it" include the right to equality, solidarity, freedom, justice and democracy (Rivera-McCutchen \& Watson, 2014). In recent years there has been a growing research interest in the issue of social justice and the developing relationship between education and leadership. This relationship is a key idea in shaping current education policy (Clark, 2018). Kant developed his own theory on this subject based on selflessness and the moral duty that each person has towards another (Zajda et al., 2020). In this way the ethical dimension of the term is emphasized. One of the most important goals of education is to provide knowledge and appropriate supplies to all learners, so that they can thrive in society. For this to happen there must be a sense of Social Justice (Bogotch \& Reyes-Guerra, 2014).

Leadership for social justice is an important idea for leadership theorists and their focus is on the high visions of equality and opportunity that are central to it (Rivera-McCutchen \& Watson, 2014). In other words, the school leader needs to treat all students on an equal footing, respecting their cultural and linguistic heritage. Of course, the existence of a strong leadership that supports all students plays an important role in this. It is therefore necessary to make ethical use of power and to resist differences and inequality (Welliamson et al., 2007).

\section{Methodology}

The survey was conducted in the summer and autumn of 2020. It involved 43 secondary school principals from public schools in Thessaly and Central Macedonia. In particular, the data were collected from 27 Gymnasiums/Junior High Schools, 11 Lyceums/High Schools, 2 Evening Gymnasiums/Junior High Schools, 2 Evening Lyceums/High Schools and 1 Technical High School. The choice of schools was made by random sampling and nowhere in the research is the personal data of the participants mentioned, thus respecting the ethical commitment to confidentiality.

The data collection was done with the research tool of semi-structured interview. In this way it is possible to interact and gather information about the subjects' experiences, feelings, values and concerns (Mills, Gay \& Airasian, 2017, p.494). Qualitative content analysis was used for their analysis. For the better collection and subsequent processing of the data, the method of transcription was used. Most of the interviews took place on the school grounds, while others due to the Covid-19 health crisis took place outside the school. In all cases the necessary personal protection measures were observed.

\subsection{What Is Content Analysis}

Content analysis is used by researchers and involves the coding of meanings in subjects' responses (Gummer et al., 2019). Thus the large set of data was gradually limited to small and important groups and then the appropriate categories and subcategories were formed. In particular, the principals mentioned the characteristics of leadership and ethical leadership, school activities, the legislative framework, the vulnerable groups. Content analysis is a research method used for systematic analysis of oral, visual or written speech 
(Downe-Wamboldt, 1992). Based on these answers, they were coded and grouped into topics deriving from the words or phrases of the participants. The sub-sections that were formed were then given the codes that helped in the evaluation and interpretation of the answers. However, through this process, information was obtained on other important issues in the context of the operation of the school units. In particular, in this case the directors expressed their views on the issues of leadership, ethical leadership and their practices for the training of vulnerable groups. The data which obtained from the 43 interviews were analyzed by the content analysis method. The variables were the codes which then became the main categories. Specifically, the principals referred to the administrative decisions, the pedagogical actions, the leadership, the management of the school units, their responsibilities as well as the legal framework that defines their duties. The main subcategories were the educational goals, the trainings and the school climate. There were similarities and differences in the views of school leaders. For example, 12 of the participants identified their role as school administrators, 9 as leaders, and 22 stated that the concepts of leadership and administration are complementary and necessary.

\section{Data Analysis}

\subsection{The Position of Leadership and Ethical Leadership in the Education System}

Initially, during the interviews, the directors express their perceptions about the terms of leadership and ethical leadership respectively. In terms of leadership, principals refer to its characteristics as vision, charisma, knowledge, guidance, integrity, justice and responsibility. On the other hand, regarding ethical leadership, they express the characteristics of empathy, equality, respect, truth, justice, honesty and integrity. Two common features are found in these two terms. Those of justice and integrity. The headmistress of a high school states briefly: "Certainly, the management of a school must be ethical, that is, it must inspire respect and honesty towards fellow human beings." Many of the principals when asked about the characteristics of leadership and ethical leadership, mentioned traits of management. That is, they identified themselves more as managers. Thus Subject 37 answers: "In the Greek school the principal often or rather presumably implements the administrative part." However, there were some who considered the concepts of leadership and management complementary and necessary for the smooth operation of schools. On the other hand, Subject 2 expresses a concern about the coexistence of ethical leadership in the Greek educational system. He characteristically states: "The system itself does not allow you to behave on the basis of ethics. It says this and this must be done. Beyond that, based on your own ethics, you need to see how far you can deviate from this whole system. It is difficult for ethical leadership to function because the law surpasses you." According to this leader, the legislation of the Greek educational system is strict and follows the rules set by the ministry, which limits the development of ethical leadership.

More specifically, the directors characterized the Greek administration system as centralized, bureaucratic with many gaps and ambiguities. All this leads to waste of time, difficulty in planning as well as lack of autonomy. The lack of accountability and evaluation of the teaching staff is particularly negative. However, the bureaucratic model according to Subject 
9 also has positive effects. "The framework in which we operate is characterized by a lot of bureaucracy. Maybe for our own safety. We are dealing with minors, children. We go on school trips and the bureaucracy is not so bad." As it turns out from this point of view, the educational rules set by the central directorate in the school units offer "confidence" to the principals because it reduces the chance of negative events that could lead to penalties.

As Saiti (2009) report, in the Greek educational system there are strong elements of bureaucracy and centralism, which form its hierarchical structure. Thus, the decisions for the school units are made pyramidically from the higher levels down. However, school principals, showing social sensitivity, try to take care of the weakest groups. For example, leader 27 , who is the principal of an evening high school, says: "Our school also enrolls ex-prisoners who study on their own in difficult conditions. We form committees to examine whether they are worthy of promotion or dismissal. Many times they are not considered worthy to be promoted, but we promote them. There is a particular sensitivity to these individuals. You can see the social conditions in which they try to study so you appreciate it ". Even in the simple daily decisions that principals make about school trips, they make sure to include all students. For this reason, they prefer to organize close visits to cultural sites that do not have a large financial burden and in which the financially vulnerable can participate. They also show tolerance for mild delinquent behaviors, in the recording of absences and organize various events to gather money intended for the financial support of vulnerable groups. Therefore, school leaders are influenced by the socio-economic situation of students in making their decisions. As stressed, the difficulties and problems of students vary and differ. Thus, principals try to mitigate externalities within the school system. The use of ethical leadership according to secondary education principals has positive effects on subordinates as value-based behavior serves as a model for them. After all, the personal virtues of leaders, self-discipline, selflessness and denial of abuse of power work positively for subordinates (Hou et al., 2019).

In schools where there is a collaborative atmosphere between administration and staff, there is a good communication climate which works positively in the educational and learning support of all students. In these cases, the pedagogical meetings of the teaching staff, in which the director is the head, give the necessary guidelines for the strengthening of the vulnerable groups. There is also consulting regarding the management of special situations in the classroom and the opportunity to share the vision. The collaborative atmosphere in the administration creates multiple benefits even in the mental health of the students.

Characteristically, Subject 22 states: "I am lucky because we have an association of teachers who have a lot of passion and willingness. So, we have activated class councils, we have meetings per department. We talk about the children who are a little more lively, the children who have learning difficulties. We talk about the students who are excellent and who have to leave this climate and take a step further ". In this particular school unit, the differentiation of learning objectives according to the capabilities of each student, acts positively because teachers are given the opportunity to implement individualized interventions. However, the educational goals of general schools differ from those of technical high schools, which emphasize the acquisition of technical skills. However, the participation of teachers in school 
administration and pedagogical planning is not taken for granted. After all, cooperation and problem-solving through democratic processes are supported by ethical principles and values, emphasizing the importance of long-term relationships (Begley \& Zaretsky, 2013). Therefore, participatory leadership and the adoption of ethical practices can contribute to the formation of a positive school climate but also to a more democratic definition of educational and learning goals.

\subsection{Pedagogical Applications of Ethical Leadership in Schools}

In the second phase, the principals record the activities that take place in their schools both for the vulnerable groups and for the whole student population. At this point the concept of vulnerable groups is defined. More specifically, leaders define as vulnerable groups of people with learning or developmental disabilities, Roma, former drug users, students from lower economic and social backgrounds, and migrants or refugees. The concentration of vulnerable groups varies depending on the type and location of the schools. For this reason, Principal 29 states: "Look, as it happens and in this case, we are an Evening High School where there are poor children and foreign children with financial issues, language issues or marginalization issues because there were children from Organization Against Drugs (OAD) with drug problems. There used to be Roma too." In some cases, students seem to have "inherited" their social or financial vulnerability from their wider family environment. In Greek society, the Ministry of Labor and Social Affairs divides vulnerable groups into two categories. Vulnerable and special population groups. It generally defines as vulnerable those groups whose participation in economic and social life is difficult either due to financial, social, physical or mental problems or due to unforeseen events. In a similar context, the European Union identifies as vulnerable groups of people at risk of poverty or social exclusion due to physical disabilities, age factors and ethnicity (Peroni \& Timmer, 2013).

The goal of the actions, according to the principals, is to include and adapt them to the education system. For example, refugee students who do not have a sufficient level of Greek fluency have difficulty in their daily activities. However, appropriate educational approaches lay the foundations for school and social inclusion, according to Leader 2, who states: "We make children sit mixed together. We do not isolate either the refugee children or the Roma. I do not ghettoize them. So, this is how friendly relations develop and because we are a semi-urban area where children can meet in the afternoon in the village square, it is easier to get closer to each other and in this way the refugees begin to learn Greek, the everyday language ". The benefits that result from these "informal" actions concern both the school and the social life of the students. In addition, there is even financial support for the vulnerable students by organizing social events: The principal of a high school where refugees attend states: "Every year we organize a bazaar, which has become an institution in our school with the support of the municipality. Revenue is available exclusively to students and their families who are in a difficult socio-economic position to meet their schooling needs." However, not all principals perform the same practices for accepting vulnerable groups as there were principals who were negative about refugees in their schools and expressed doubts about the intentions of Non-Governmental Organization (NGO) such as Principal 11: "And I also have a negative attitude towards refugees. Unfortunately, we can 
not support the children in high school. They have to go to special schools. "But at the request of NGOs, they enroll in schools to get the benefits." But in other cases, the cooperation with the organizations, the local bodies and the special educational staff works in favor of school integration. For example, Principal 40 says: "If I shout at, scare and expel a child who belongs to a vulnerable group, they will not stay in school. And if they do, they are not going to do anything. But if I explain why they are here, the social responsibility, what we need to do to move forward, I get in touch with the parent, I work with the psychologist or the social worker, of course the child will stay in school and will also do better". The principal therefore uses ethical methods to reduce school dropout and to mobilize the children's interest in learning.

The school leaders about educational activities mentioned the institutional ones, those determined by the Ministry of Education, and the non-institutional or informal ones. In the activities carried out in the school units for the educational support of the vulnerable groups, the leaders include didactic visits to cultural and social spaces, supportive teaching, mental health programs, theatrical performances and various European student exchange programs. At this point it should be noted that as much of the research was carried out in the autumn of 2020, after the first phase of the pandemic, there were still restrictions, which put obstacles in the implementation of actions and programs.

One of the problems mentioned by the principals is the lack of financial resources with which they are not able to cover the school expenses for the purchase of consumables such as sponges and markers. However, some consider it adequate with proper management. Regarding, the issues of training, most of the directors stated that it is not their responsibility, and it is the responsibility of the Ministry of Education to organize training seminars. However, some principals, such as Subject 30, said that training initiatives were needed: "For instance, last year we had a training course from the entire board of the counseling and support center in eastern Thessaloniki. It is an area that I really pursue because I believe that teachers need to be informed about current developments in pedagogical issues." Leaders who reported in-school training included these updates on student psychological support and first aid.

\section{Results}

Through this research some useful results can be drawn regarding the role of the principal and the effects it has on the whole school unit. Initially, the exercise of ethical leadership in place of just management, in the context of school organization, works as an aid to the educational support of students. Indeed, students with special social or cultural characteristics integrate more easily and successfully into the school environment when a sense of justice and equality are present. At the same time, the pedagogical actions taken by the leaders on their own initiative instead of the institutionalized activities, work in addition to strengthening the vulnerable groups. In addition, in this way the school climate is improved and a culture of coexistence between the different groups is established. On the other hand, the participation and cooperation of the leaders with the rest of the school staff contributes to the cohesion of the team as well as to the more effective administration because in this way 
there is a plurality of views. This gives teachers the opportunity to implement individualized interventions for students. The integration practices applied in the school environment can create the appropriate conditions in society. In other words, educational support for vulnerable groups can have a positive effect on their socialization.

\section{Discussion}

The application of ethical leadership can improve students' learning performance and enhance their social inclusion. In this context, school principals through the use of moral values and appropriate behaviors are the model for other members of the educational community. In addition, the ethical use of power by leaders seems to allow staff involvement and cooperation that contributes to the implementation of individualized interventions for students and vulnerable groups. In other words, it stimulates interest in vulnerable groups. Also, in order to promote inclusive education for vulnerable social groups it is important to exercise leadership and not just simple management of the school unit.

At this point it should be noted that due to the Covid-19 health crisis the activities of school units to support vulnerable groups have been greatly reduced and this is a problem. In this context, the lack of infrastructure and clarity from the political leadership was a particular problem for the management of the health crisis at the school level (Karadimou \& Tsioumis, 2021). That is to say, the principals did not have pre-determined mandates even for carrying out the training activities. Social vulnerability as Kyridis (2014) points out is a social problem. For this reason, the shielding of these groups in the context of ethical school leadership has numerous and important benefits even for society itself.

However, the bureaucratic and centralized system of organization and administration of the Greek educational system limits the undertaking of initiatives by the principals. Many of them are reluctant to take action beyond what is legal because they fear sanctions. But in some cases, the principals, being empathetic, try through individual efforts and with innovative actions to integrate the vulnerable groups in day to day school life. On the other hand, the legislative framework does not clearly define the organization and implementation of training programs that can assist in the renewal of knowledge. But ethical leadership and the adoption of its practices can be one of the effective methods of managing educational organizations.

\section{Acknowledgments}

The present research was carried out within the framework of the Postgraduate Program "Lifelong Learning and Leadership in Education" of the Department of Preschool Education of the Aristotle University of Thessaloniki.

\section{References}

Ahmad, A. R., Adi, M. N. M., Md Noor, H., Rahman, A. G. A., \& Yushuang, T. (2013). The influence of leadership style on job satisfaction among nurses. Asian Social Science, 9(9), 172-178. https://doi.org/10.5539/ass.v9n9p172 
Almandeel, S., \& Dawood, M. (2019). The Relationship between Ethical leadership and Teachers Continuance Organizational Commitment, 12(1), 2279-2294.

Arar, K., Haj, I., Abramovitz, R., \& Oplatka, I. (2016). Ethical leadership in education and its relation to ethical decision-making: The case of Arab school leaders in Israel. Journal of Educational Administration, 54(6), 647-660. https://doi.org/10.1108/JEA-11-2015-0101

Athanasoula-Reppa, A. (2008). Educational Management and Organizational Behavior. Athens: Ion

Begley, P. T., \& Zaretsky, L. (2013). Democratic school leadership in Canada's public school systems: Professional value and social ethic. Journal of Educational Administration, 51(4), 640-655. https://doi.org/10.1108/09578230410563647

Berkovich, I. (2014). A socio-ecological framework of social justice leadership in education. Journal of Educational Administration, 52(3), 282-309. https://doi.org/10.1108/JEA-12-2012-0131

Bogotch, I., \& Reyes-Guerra, D. (2014). Leadership for Social Justice: Social Justice Pedagogies Liderazgo para la Justicia Social: Pedagogías de Justicia Social Liderança para a Justiça Social: Pedagogicas para a Justiça Social In this article, the authors examine how the many pedagogical, 3(2), 33-58.

Bourandas, D. (2005). Leadership: The path to lasting success. Athens: Kritiki

Brown, M. E., \& Treviño, L. K. (2006). Ethical leadership: A review and future directions. Leadership Quarterly, 17(6), 595-616. https://doi.org/10.1016/j.leaqua.2006.10.004

Clark, J. A. (2018). Social Justice, Education and Schooling: Some Philosophical Issues Published by: Taylor \& Francis, Ltd. on behalf of the Society for Educational Studies Stable. https://doi.org/10.1111/j.1467-8527.2006.00352.x

Cranston, N., Ehrich, L. C., \& Kimber, M. (2006). Ethical dilemmas: The "bread and butter" of educational leaders' lives. Journal of Educational Administration, 44(2), 106-121. https://doi.org/10.1108/09578230610652015

Dougali, E. (2017). Leadership style and professional satisfaction of teachers: A quantitative survey of the views of Primary education teachers. In S. Giosi, E. Balkanos, A. Economou, (Eds.), 1st International Scientific Conference, Volume II, "Educational Leadership, Effective Management and Ethical Values, November 24-26, 2017 (pp. 129-141). Thessaloniki: University of Macedonia

Downe-Wamboldt, B. (1992). Content analysis: Method, applications, and issues. Health Care for Women International, 13(3), 313-321. https://doi.org/10.1080/07399339209516006

Ehrich, L. C., Harris, J., Klenowski, V., Smeed, J., \& Spina, N. (2015). The centrality of ethical leadership. Journal of Educational Administration, 53(2), 197-214. https://doi.org/10.1108/JEA-10-2013-0110 
Gummer, T., Blumenberg, M. S., \& Roßmann, J. (2019). Learning effects in coders and their implications for managing content analyses. International Journal of Social Research Methodology, 22(2), 139-152. https://doi.org/10.1080/13645579.2018.1503789

Gunter, H. M., \& Forrester, G. (2009). School leadership and education policy-making in England. Policy Studies, 30(5), 495-511. https://doi.org/10.1080/01442870902899947

Hou, B., Hong, J., Zhu, K., \& Zhou, Y. (2019). Paternalistic leadership and innovation: the moderating effect of environmental dynamism. European Journal of Innovation Management, 22(3), 562-582. https://doi.org/10.1108/EJIM-07-2018-0141

Kalshoven, K., \& Boon, C. T. (2012). Ethical leadership, employee well-being, and helping the moderating role of human resource management. Journal of Personnel Psychology, 11(1), 60-68. https://doi.org/10.1027/1866-5888/a000056

Karadimou, M., \& Tsioumis, K., (2021). Is citizenship education the "vaccine” for Covid-19 educational consequences? Conference: Political and economic self- constitution: education for digital citizenship in post-pandemic times, 34-37.

Kyridis, A. (2014). Vulnerable social groups and lifelong learning. Athens: Gutenberg

Langlois, L. (2014). Development and validity of the Ethical Leadership Questionnaire. July 2016. https://doi.org/10.1108/JEA-10-2012-0110

Lawton, A., \& Páez, I. (2015). Developing a Framework for Ethical Leadership. Journal of Business Ethics, 130(3), 639-649. https://doi.org/10.1007/s10551-014-2244-2

Mills, G., Gay, L. R., \& Airiasian, P. (2017). Educational Research, Competencies for analysis and applications. (10th Ed.) Publications: Propompos.

Mitropoulou, E-M., Tsaousis, I., Xanthopoulou D., \& Petridis K. 2014). Looking for the characteristics of a moral leader. An empirical study in the workplace. Psychology, 21(1), 161-182. https://doi.org/10.12681/psy_hps.23274

Peroni, L., \& Timmer, A. (2013). Vulnerable groups: The promise of an emerging concept in European Human Rights Convention law. International Journal of Constitutional Law, 11(4), 1056-1085. https://doi.org/10.1093/icon/mot042

Rivera-McCutchen, R. L., \& Watson, T. N. (2014). Leadership for Social Justice. Journal of Cases in Educational Leadership, 17(4), 54-65. https://doi.org/10.1177/1555458914549663

Saiti, A. (2009). The development and reform of school administration in Greece: A primary school perspective. Educational Management Administration and Leadership, 37(3), 378-403. https://doi.org/10.1177/1741143209102790

Seidman, D. (2004). The case for ethical leadership. Academy of Management Executive, 18(2), 134-138. https://doi.org/10.5465/ame.2004.13836070 


\section{Macrothink}

Tumasjan, A., Strobel, M., \& Welpe, I. (2011). Ethical Leadership Evaluations After Moral Transgression: Social Distance Makes the Difference. Journal of Business Ethics, 99(4), 609-622. https://doi.org/10.1007/s10551-010-0671-2

Walker, A., Haiyan, Q., \& Shuangye, C. (2007). Leadership and moral literacy in intercultural schools. Journal of Educational Administration, 45(4), 379-397. https://doi.org/10.1108/09578230710762418

Welliamson, J. A., Rhodes, L., \& Dunson, M. (2007). A selected history of social justice in education. Review of Research in Education, 31(2007), 195-224. https://doi.org/10.3102/0091732X07300465

Zajda, J., Majhanovich, S., \& Rust, V. A. L. (2020). Introduction: Education and Social Justice Author (s): Joseph Zajda, Suzanne Majhanovich and Val Rust Source: International Review of Education / Internationale Zeitschrift für Erziehungswissenschaft / Revue Internationale de l' Education, 52(1), 9-22. https://doi.org/10.1007/s11159-005-5614-2

\section{Copyright Disclaimer}

Copyright for this article is retained by the author(s), with first publication rights granted to the journal.

This is an open-access article distributed under the terms and conditions of the Creative Commons Attribution license (http://creativecommons.org/licenses/by/4.0/). 